\title{
Performance Multiple Objective Optimization of Irreversible Direct Carbon Fuel Cell/Stirling Thermo-Mechanical Coupling System
}

\author{
Liwei Chen ${ }^{1,2}$, , Yingyan Lin ${ }^{1}$ \\ ${ }^{1}$ School of Mechanical \& Electronic Engineering, Sanming University, Sanming 365004, China; \\ ${ }^{2}$ Department of Physics, Chemnitz University of Technology, Chemnitz 09111, Germany. \\ ${ }^{*}$ E-mail: $125601497 @$ qq.com
}

doi: $10.20964 / 2020.01 .04$

Received: 12 August 2019 / Accepted: 16 October 2019 / Published: 30 November 2019

\begin{abstract}
Modern Stirling engine has been paid more and more attention because of its wide adaptability of various energy sources and excellent environmental characteristics. In this paper, Stirling engine is selected as the secondary energy device of direct carbon fuel cell to construct a new coupling system. Through electrochemical and thermodynamic derivation, the performance expression of coupling system is obtained. The results show that the performance of the coupling system is positively correlated with the working temperature. At the same time, a multi-objective function is introduced to give the corresponding working interval according to the engineers' different preferences for the power output and efficiency.
\end{abstract}

Keywords: irreversible Stirling engine; Direct carbon fuel cell coupling system; Performance study, multiple objective optimization

\section{$\underline{\text { FULL TEXT }}$}

(C) 2020 The Authors. Published by ESG (www.electrochemsci.org). This article is an open access article distributed under the terms and conditions of the Creative Commons Attribution license (http://creativecommons.org/licenses/by/4.0/). 